Rosen, Ilana. "The Representation of Jews in Nineteenth- and Twentieth-Century Hungarian Proverb Collections." Hungarian Cultural Studies. e-Journal of the American Hungarian Educators Association, Volume 10 (2017) DOI: 10.5195/ahea.2017.280

\title{
The Representation of Jews in Nineteenth- and Twentieth-Century Hungarian Proverb Collections
}

\section{Ilana Rosen}

Abstract: Proverbs are concise formulations of folk wisdom and as such, when seen in masses, they may well express the spirit of their time and place. In Hungarian proverbial lore Jews figure prominently in nineteenth-century proverb collections but fade out of such collections as of the mid-twentieth century. In the nineteenth-century proverb collections Jews are invariably portrayed as faithless, dishonest, greedy, physically weak and unattractive. Largely, this portrayal as well as the dynamics of the earlier presence of Jews versus their later disappearance from Hungarian proverb collections match the shared history of Hungarians and Hungarian Jews since the 1867 Emancipation of the country's Jews and possibly even earlier, through their growing integration in significant arenas of their host society, up to their persecution and annihilation in the Holocaust, and later their decade long forced merging into the general Hungarian society under communism. This article traces the occurrence and disappearance of Jews in Hungarian proverb collections throughout the last two centuries and analyzes the language, content and messages of the proverbs about Jews in these collections.

Keywords: Hungarian Jews, Emancipation, proverbs and sayings, stereotype, András Dugonics, János Erdély, Andor Sirisaka, Ede Margalits, Gyula Paczolai, Gabriella Vöö

Biography: Ilana Rosen ( $\mathrm{PhD}$, Hebrew $\mathrm{U})$ is Professor of Hebrew Literature at the Ben Gurion University of the Negev in Beer Sheva, Israel. She studies the folk and documentary literature of Diaspora Jews and of Israelis in the twentieth century and has devoted to these topics over forty articles and five books, including Soul of Saul - the Life, Narrative and Proverbs of a Transylvanian-Israeli Grandfather (2011). As of 2013, she is the Book Review Editor of Hungarian Cultural Studies. ilanaro@bgu.ac.il

Proverbs are one of the minor or gnomic genres of folklore, like jokes, riddles, nicknames, inscriptions, and lately also ads, stickers and signs in all possible media. In their form proverbs are short non-narrative discourse units and in their content and function they are transmitters of definitive messages about how this world works, what we should think, and how we should live and act. Proverbs are believed to be, by their users and audiences, a kind of "truth" and therefore a dictate to follow. Proverbs may include rhymes and puns as mnemonic means but they may also flatly repeat known facts and still convey powerful messages. In folkloristics proverbs are seen as concise formulations of folk wisdom of various communities like national, ethnic, regional, age, gender, religion/faith, life-style, professional and many other 
Rosen, Ilana. "The Representation of Jews in Nineteenth- and Twentieth-Century Hungarian Proverb Collections." Hungarian Cultural Studies. e-Journal of the American Hungarian Educators Association, Volume 10 (2017) DOI: 10.5195/ahea.2017.280

larger or smaller peer groups; and as such, when examined in masses, proverbs express the spirit of their "folk," time, and place.

Proverbs can be uttered, adopted and repeated, or rejected or altered, or even abused through anti-proverb creation dynamics (Reznikov 2009); but without proper, systematic recording they might remain unknown to anyone outside their immediate users. Therefore, the collection and preservation of proverbs, either in alphabetical lists according to the keyword in each proverb, or following associative, thematic lines of thought, has been a known practice since ancient times, with the Biblical Book of Proverbs, Mishlê, attributed to the Israelite King Solomon (Heb. Shlomo) of the tenth century BC, serving as a proto-compilation. Making a long leap, geographically northward and periodically three thousand years forward, to nineteenthcentury Europe, the rise of modern national notions and, with them, the view that the nation's spirit is embedded in and expressed by its folk narratives, songs, and wise sayings enhanced a huge wave of compilation projects of both major genres like legends and tales and minor genres like proverbs and sayings. Later, throughout the twentieth century, recording of all genres continued by both professional folklorists and amateur collectors, and nowadays, with the growing impact of electronic media, the fruit of all these recording projects is becoming ever more accessible to large audiences.

This article examines the portrayal and image of Jews in several nineteen- and twentiethcentury Hungarian proverb collections, with dafka the earlier ones presently made more accessible on the Internet by the Magyar elektronikus könyvtár MEK ['Hungarian Electronic Library'] and with the later collections still less available as presently existing mostly only in print. The nineteenth-century collections are the following: poet and philosopher János Erdély's 1851 Magyar közmondások könyve ['Book of Hungarian Proverbs'], published by the Budapest Kisfaludy Társaság or Association, which, in keeping with the winds of its time, supported the preservation and publication of Hungarian folklore, and which Erdély (1814-1868) was a member of (Erdély 1851); Andor Sirisaka's 1890 independently published volume carrying the exact same title as Erdély's collection and published in Pécs(ett) (Sirisaka 1890); and Ede Margalits's much larger and more detailed volume, Magyar közmondások és közmondásszerü szólások ['Hungarian Proverbs and Proverbial Sayings'] (Margalits 1896). Margalits's collection was published by the Magyar Tudományos Akadémia ['the Hungarian Academy of Sciences'] and supported by the Kisfaludy Társaság that published Erdély's collection, although by then the Association as a formal organization no longer existed. Margalits (1849-1940), a Jewish scholar and writer who - contrarily to the norm of Hungarian-Jewish intelligentsia of his time and later — never changed his Hebrew last name (meaning gem ['gyémánt'] or pearl ['gyöngy']) to a Hungarian name, wrote dozens of studies and essays, with quite a few of them devoted to proverbs and sayings.

Underlying these three compilations, at least partly, as I learned from looking for explications for some obscure-sounding proverbs in them, like "Ki néz a bótbúl, mint a Mori Zsidó" ['Looking out of the/his shop, like the Jew of Mór (small town in Northwestern Hungary)' (Dugonics 206)], "Se kin se ben mint zsidó a lóban" ['Neither outside nor in, like the Jew in the horse'], and Benne van, mint a zsidó a lóban ['He is inside, like the Jew in the horse'] (Margalits Benn) (with no Trojan notions intended...), is an even earlier nineteenth-century source; this source is the language-use textbook published in 1820 and composed by the Szeged teacher and writer András Dugonics (1740-1818), entitled Magyar példa beszédek és jeles mondások ['Hungarian Exemplary Speech and Outstanding Sayings'] (Dugonics 1820). Though not strictly 
Rosen, Ilana. "The Representation of Jews in Nineteenth- and Twentieth-Century Hungarian Proverb Collections." Hungarian Cultural Studies. e-Journal of the American Hungarian Educators Association, Volume 10 (2017) DOI: 10.5195/ahea.2017.280

and formally (meaning in its form, like its line layout) a proverb collection, nevertheless, Dugonics's posthumously published textbook includes many proverbs and sayings as well as explanatory notes that reveal his and probably his time's attitude toward their scope; and actually it is also included together with the other three nineteenth-century collections within one online volume entitled Régi magyar szólások és közmondások ['Old Hungarian Sayings and Proverbs'], with a Preface by Tamás Forgács, at: http://mek.oszk.hu/09100/09112/html/index.html), in addition to each of them appearing separately on the $M E K$.

The interpretation of seemingly innocent language-use textbooks, dictionaries and lexicons as telling cultural texts comes close to Éva Szöllösy's 2015 study, A férfiak és a nök képe modern értelmezö szótárainkban ['The Image of Men and Women in Our Modern Hungarian Dictionaries'], in which Szöllősy applies a gender-sensitive linguistic scrutiny to several contemporary Hungarian dictionaries only to conclude that despite their communisminspired proclaimed gender-equality, in many cases these dictionaries continue to demonstrate outright misogyny. This comes through in explanatory descriptions such as: "My grandfather was a respected professor of biology," as opposed to: "His/her mother was a general practitioner and not a specialist" (Szöllősy 2015, Sándor 2016). Returning to proverbs, looking up other publications by all four nineteenth-century copious authors and editors, one realizes the extent to which all of them, including the Jewish Margalits, partook of their time's interest in the Hungarian folk and its spirit and sentiments, as expressed in its folk songs, children's stories and proverbs and sayings. As I later propose, this motivation may have influenced their choices of inclusion and omission of materials all in the effort to present and preserve a consolidated image of the Hungarian folk, including its disregarding and demeaning of its Others.

The twentieth-century Hungarian proverb collections include, first and foremost, the renowned paremiologist Gyula Pczolay's 1991 compilation 750 Magyar közmondás ['750 Hungarian Proverbs'] (Paczolai 1991), many of which recur in his 1997 inclusive and comparative volume featuring one hundred and six proverbs in fifty-five languages, Európai közmondások 55 nyelven - arab, perzsa, szanszkrit, kínai és japán megfelelökkel ['European Proverbs in 55 Languages with Equivalents in Arabic, Persian, Sanskrit, Chinese and Japanese'] (Paczolai 1997). The third and last is Gabriella Vöö's Igaz ember igazat szól - közmondások a romániai magyar folklórból ['A Truthful Man Speaks the Truth - Proverbs of the RomanianHungarian Folklore'] (Vöö1989). There are of course many more academic and non-academic contemporary collections, but these three are representative of most if not all of them in their minimal reference to Jews.

When looking up — or looking for-references to Jews in the seven collections covering two centuries of Hungarian proverb lore, we find that such proverbs figure prominently in the four nineteen-century collections: thirty-nine references in Dugonics's textbook, nineteen in Erdély's collection, eleven in Sirisaka's, and over forty in Margalits's more detailed and scientifically-edited collection. All these make a sum-total of one hundred and ten items; minus many recurring ones, plus a few equivalents, altogether they make up a corpus of approximately seventy to eighty proverbs and sayings about Jews. For comparison, these same four collections also relate to other minorities and foreigners. In Dugonics's textbook there are some twenty proverbs and sayings about Roma people, then called Gypsies (Hung. Cigány or Czigány) and a few others about Turks, Germans, Greeks, Poles and Russians. In Sirisaka's collection, too, this is the ratio, plus two sayings about Wallachian Romanians (called Oláh). Erdély's collection is much more preoccupied than all the others with Gypsies, featuring over fifty proverbs and 
Rosen, Ilana. "The Representation of Jews in Nineteenth- and Twentieth-Century Hungarian Proverb Collections." Hungarian Cultural Studies. e-Journal of the American Hungarian Educators Association, Volume 10 (2017) DOI: 10.5195/ahea.2017.280

sayings about them, as well as ten about Turks, ten about Germans, four about Greeks, two about Poles and one about Italians. In Margalits's collection there are twenty-five proverbs and sayings about Gypsies, one about Italians and one about Russians. The content of most of these proverbs and sayings, in all four collections and about whichever group, is belittling and derisive, often criticizing the group's stupidity or other inadequacy; and in the case of Gypsies they are more widely described as lazy, filthy, liars, worthy of beating, tasteless and promiscuous. When compared to the number and content of the proverbs and sayings about Jews in the four nineteenth-century collections, only the Gypsies earn as much attention yet their portrayal is far less diverse as well as on-the-whole less bitingly hostile than that of Jews.

Women also comprise a group unto itself in the four nineteenth-century collections, wherein, as also shown in several proverb studies from other cultures, the proverbs and sayings indirectly, though far from subtly, guide the group's women as to what is considered appropriate behavior (Kerschen 2000, Hussein 2009, Diabah and Amfo 2015). Being modest, diligent, submissive, subservient, reproductive, and not too outspoken are all hailed traits whereas their opposites are condemned (e.g., Hallgatással szép az aszonyember ['Women folk are beautiful when silent'] (Erdély 284). In general, though degrading and sexist, the proverbs and sayings about women aim at educating or manipulating them, whereas those about minorities and foreigners unconditionally condemn these various Others.

In the late twentieth-century collections representing the age of communism and its early aftermath almost no allusions to Jews can be found, excluding two in Vöö's collection of Romanian-Hungarian folklore, in which Jews are listed as part of other Others such as gentry or clergy or Roma/Gypsy people, whom it is better to fear or get rid of. These are: Gróf barátságától, zsidó ölelésétöl, pap bosszújától kell félni ['An earl's friendship, a Jew's hug, and a priest's revenge are to be feared'] (Vöö 1989, 98, F 150); and Pakolj Sári, Mózes, zsidó, múlik a vásár ['Pack up Sarah, Moses, Jew, market day is almost over'] (Vöő 1989, 269, V 83). Andrei Oişteanu, in his Inventing the Jew - Antisemitic Stereotypes in Romanian and Other CentralEast European Cultures (Oişteanu 2009, 25-26), considers the fade-out of Jews from Romanian and other Central-European folklore collections the result of the communist tabooing of Jews in, or rather out of, the cultures of these societies.

As I will show in some detail, when Jews are still present in Hungarian proverb collections, meaning in those of the nineteenth-century, they are invariably portrayed in them as faithless or with the wrong faith, dishonest, greedy, physically weak and unattractive verging on repulsive. Largely, this negative and stereotypical portrayal (on the structuring and mechanism of which see: Zenner 1970; Mieder 2006) of Jews in the nineteenth-century collections, as well as the disappearance of Jews from the twentieth-century collections, match the shared history of Hungarians and Hungarian Jews in the nineteenth and twentieth century. This shared history, from a bird's eye-view, starts with the late eighteenth-century and early nineteenth-century allEuropean Enlightenment and national revival, and then - in the case of Hungary and its Jewsgoes on to the 1867 Hungarian Emancipation of the country's Jews. Although progressive for its time, seen in retrospect the Emancipation, besides deepening the division between traditional or shtetl Jews and modern ones, exacerbated rather than solved the "Jewish Question," meaning the debate over the place of Jews within their Hungarian host-society; because now it turned out that whereas the shtetl Jews were guilty of self-segregation and of pulling society at large toward poverty and primitiveness, the modern, educated and professional Jews were accused of robbing society of its resources like education and well-paying jobs, and of hiding or camouflaging their 
Rosen, Ilana. "The Representation of Jews in Nineteenth- and Twentieth-Century Hungarian Proverb Collections." Hungarian Cultural Studies. e-Journal of the American Hungarian Educators Association, Volume 10 (2017) DOI: 10.5195/ahea.2017.280

Jewishness by adopting the dress and lifestyle of their non-Jewish environment. In her The Invisible Jewish Budapest, Mary Gluck explores how greatly the capital city's Fin-de-Siècle popular culture thrived by virtue of assimilated Jews and converts to Christianity (Gluck 2016). Later, in the 1920s and 1930s, the allegations against such Jews as parasites and profiteers led to Numerus Clausus laws limiting the number of Jews entitled to enter higher education to their percentage in the general population; and though the original law or "Act" was amended in 1928, it's spirit persisted and affected legislation throughout the 1930s and then to the end of War World II (Kovács, M.M. 2012, Kovács, T. 2014).

In 1938-1941 three "Jewish Laws" that defined Jews in racial terms gradually deprived them of all civil rights and eventually, inspired by the Nazi-German Final Solution ['Endlösung'] led to their 1944-1945 persecution and annihilation in World War II and the Holocaust. World War II was almost immediately followed by four decades of Soviet-ruled communism in the entire East-Central Europe, and with them came a general silencing of any talk or writing on particularly Jewish suffering in the war or on specifically Jewish issues within the Hungarian communist or Workers' society. As of the 1989 falling apart of the Soviet bloc Jewish issues are again allowed in discussions of Hungarian history and culture, and with them also old and new, religious and political, and lately even anti-Israeli anti-Semitism (Braham 1994, Patai 1996, Szalai 2002).

Focusing again on the nineteenth century, when Jews still figured even if far from favorably in Hungarian proverb collections, their negative portrayal did not evade the eyes of Jewish intellectuals living in the mid nineteenth-century to the mid twentieth-century. The aforementioned Zagreb-born and later Budapest-resident Ede Margalits was familiar, as said, with the proverbial lore of several Austro-Hungarian subgroups and thus acquired a well-rounded comparative, not to say relativist and detached, perspective on the nature and spirit of the folk materials he encountered. The same is true of Chief Rabbi Ármin Flesch (1866-1944) of Mohács, in southern Hungary, who ended his life in the Auschwitz death-camp and who, in additional to rabbinical instructive writings had also published in 1908 a survey article about "The Jew in Hungarian proverbs" ('A zsidó a Magyar közmondásban,' Flesch 1908; Görög-Karady 1992). These Emancipation-Era Jewish scholars had good reasons to perceive the negative characterization of Jews in the corpora they studied as a remainder of less progressive times for the integration and acceptance of Jews into Hungarian society.

Holocaust history proved the hopes of Jewish intellectuals such as Margalits and Flesch as well as those of assimilates and converts like those in Gluck's study wrong, with more than half of Great Hungary's 800,000 Jews belonging to all persuasions and shades systematically murdered in 1944-1945, many thousands of them by the hands of their Hungarian fellowmen. Therefore, looking on these seventy-to eighty nineteenth-century openly Jew-hating proverbs and sayings, we might now, in retrospect, read them both historically (meaning, as the result of historical events and cultural processes) and genealogically (meaning, as leading to or at least influencing historical events and cultural processes). One way or another, these dozens of proverbs and sayings constitute a corpus reflecting what the Hungarian people at large, including both ordinary proverb mongers and learned proverb collectors, both Christians and Jews, thought and felt, or felt they should think, about the Jewish Hungarians of their time.

In what follows I examine dozens of proverbs and sayings including: proverbs per se, which are concise sayings made up of proper sentences that make a claim, like Zsidó nem ad a voltra ['A Jew does not pay a past debt'] (Dugonics 89, Erdély 8541); proverbial sayings, 
Rosen, Ilana. "The Representation of Jews in Nineteenth- and Twentieth-Century Hungarian Proverb Collections." Hungarian Cultural Studies. e-Journal of the American Hungarian Educators Association, Volume 10 (2017) DOI: 10.5195/ahea.2017.280

meaning proverb-like descriptions rather than claims, like Sok zsidó gyermeket felnevelt már életében ['He has supported the education of many a Jewish child in his lifetime'] (Margalits Felnevel); metaphoric sayings/speech, namely, proverb-like metaphor-based descriptions, like Zsidószagu a kendöd hugom ['Sister, your shawl smells Jewish' (meaning you bought it on credit)] (Margalits Kendö); and idioms, which are predicate-less short sayings, metaphoric or other, like Zsidó vecsernye ['Jewish evening-prayer'] (deriving from Russian вечеp/vyecher and/or Polish wieczór, meaning evening, Erdély 8555, Margalits Lárma) (for a detailed subgenre division of proverbs and sayings see: Rosen 2011, 26, N35).

Looking at the proverbs and sayings about Jews in the four nineteenth-century collections of Dugonics, Erdély, Sirisaka and Margalits, we should first note their common linguistic traits. In their form and function, most of these seventy-to-eighty proverbs and sayings are authoritative indicators, or assertions, proclaiming that Jews are this or that, or like this or that, rather than employing more open-ended dialogic exchanges, question-and-answer sequences, or conditional phrases, like Ki nem kiván öreg lenni, akaszsza fel magát ['Whoever does not wish to get old should hang themselves'] (Erdély 6091) or Ha papucsot adsz neki, csizmádat is kéri ['If you give him slippers, he will also ask for your boots'] (Margalits Papucs), that would have made these proverbs and sayings less decisive and which frequently occur in the four collections when not dealing with Jews. Exceptions to this rule are the two conditional sayings: Ha te vered az én zsidómat, én is verem a tiedet ['If you beat my Jew, I too will beat yours'] (Erdély 8544), and Becsületes ember, ha zsidó nem volna ['A decent man, were he not Jewish'] (Margalits Becsületes).

In their syntax, besides featuring Jews as grammatical-semantic object rather than subject or as discussant, as happens in the last two conditional proverbs I just introduced, many of the proverbs and sayings about Jews start with the conjunction "even," thus making the case of Jews an exception, a possibility to be considered but not at first thought. Examples of such reserved inclusion are: Még a Zsidónak is ki tér ['He might even convert to Judaism'] (Dugonics 4); Zsidó is megverte fiát, mikor elöször nyert ['Even (the) Jew beat his son when he first won' (in a card game), meaning did better than his father] (Erdély 8540; Sirisaka Zsidó); Zsidók közt is legöregebb hajtja a lovat ['Even among the Jews the oldest drives the horse'] (Erdély 8542; Sirisaka Zsidó); Zsidónak is szent aszony Mária ['Even for a Jew Mary is a saint woman'] (Erdély 8553; Margalits Mária); Zsidó is szereti Máriát, a körmöczi aranyon ['Even the Jews likes/adores Mary, (engraved) on Kremnica gold'] (Sirisaka Zsidó; Margalits Körmöc); and a variant of the former: Zsidó is szereti Máriát a márjáson ['Even the Jew likes/adores Mary on the coin bearing her image'] (Margalits Mária).

In many other proverbs and sayings in the four nineteenth-century collections the reference to Jews and their ways of life is postponed to the end of the utterance, using the preposition "like," and then-sometimes employing a comic caesura logic_-offering a far from complimentary example. This very large group of persons, actions, and situations affiliated with Jews through likening can be further sub-divided. The first subgroup consists of comparisons between the religions and traditions of Christians and Jews wherein the latter inevitably emerge as inferior. Examples of these are: Oly gyüleközet, melyben a fülnek semmi gyönyörüsége nincsen, mint a Zsidó templomban ['Such a gathering in which the ear finds no beauty, as in a Jewish prayer house'] (Dugonics 134); Ugy lármáznak, mint a zsidó vecsernyén ['They make such noise as in the Jewish Evening Prayer'] (Erdély 8555; Margalits Lárma); Úgy fél, mint Zsidó a köröszttül ['Afraid like the Jew of the Cross'] (Dugonics 146); Fél, mint nagy Pénteken a Zsidó 
Rosen, Ilana. "The Representation of Jews in Nineteenth- and Twentieth-Century Hungarian Proverb Collections." Hungarian Cultural Studies. e-Journal of the American Hungarian Educators Association, Volume 10 (2017) DOI: 10.5195/ahea.2017.280

['Afraid like a Jew on Good Friday'] (Dugonics 208; Margalits Nagypéntek); Remeg mint a zsidó az akasztófa alatt ['Shakes like a Jew under the gallows'] (Margalits Remeg); Megszokta mint Ábrahám zsidó a csalást ['He got used to it like Abraham the Jew (got used) to cheating'] (both in: Margalits Ábrahám).

The second subgroup with "like" lists the negative traits of Jews and things affiliated with them, like money, featuring proverbs and sayings that portray Jews as faithless, deceitful, and cunning. These are: Hitetlen, mint a Zsidó ['Faithless, like a Jew'] (Dugonics 221; Margalits Hitetlen); Élelmes mint a zsidó ['Practical like a Jew'] (Margalits Élelmes); Alkuszik mint zsidó a gyapjura ['Bargains like a Jew about wool'] (Erdély 8550; Margalits Alkuszik); Ravasz mint a Görög-Zsidó ['Cunning like a Greek-Jew'] (Dugonics 176; Erdély 8552); Ájtatos mint a koldus zsidó ['Pious like a Jewish beggar'] (Margalits Ájtatos); Hamis mint a zsidó fontja ['Forged like the Jew's Pound'] (Margalits Font); Csal[,] mint a zsidó ['Cheats(,) like the Jew'] (Dugonics 172, 201); Megcsalta mint zsidó a lovát ['He cheated him like a Jew cheats his own horse'] (Margalits Megcsal); Megvagyok mint a zsidó fontja ['I get along like the Jew's Pound'] (Erdély 8547; Margalits Font). Finally, Van, mint a zsidónak szalonnája ['We have it like a Jew has bacon'] (Erdély 8546) denotes in relatively neutral terms that something does not exist just as Jews would not be in possession of pork.

In the third subgroup with "like" Jews are depicted as restless, weak, and miserable. These are: Nincs nyugta, mint a bolygó zsidónak ['Has no rest, like the wandering Jew'] (Margalits Bolyong; Scheiber 1954); Jár/Mászkál mint a zsidóban a fájás ['Comes and goes like pain in a Jew'] (Margalits Fájás, Mászkál; Ember 1988); Hét országra szól, mint a zsidó kalendárium ['Speaks of seven countries, like the Jewish calendar'] (Margalits Kalendárium); Kipakkolt, mint az egygombu zsidó ['He unpacked, like a Jew owning one button'] (Margalits Kipakkolt); Köpköd mint a zsidó ['Spits like a Jew'] (Margalits Köp); Lót-fut mint a börszedö zsidó ['Runs around like the skin-collector Jew'] (Margalits Lót-fut ); Megjárta mint a mádi zsidó ['He made the route of, meaning he had a bad experience, like the Jew of Mád'] (Margalits Mád, Ben-Amos 2007: 407-409, Rosen 2011: 89); Illik neki, mint zsidónak a puska ['It suits him like a rifle (suits) a Jew'] (Margalits Puska), and Fel se veszi, mint a vadászó ember a zsidót ['Would not even hire him, like a hunter would not hire a Jewish helper'] (Margalits Vadász), with the last two sayings depicting Jewish men as weak and cowardly, or lacking in masculinity, an issue I will address at more length later in this article.

The fourth and last subgroup with "like" can be called miscellaneous and it consists of the three metaphoric sayings shortly cited before from Dugonics's textbook about a Jew in a shop or in a horse. Of these, Ki néz a bótbúl, mint a Mori Zsidó ['Looking out of the/his shop, like the Jew of Mór'] (Dugonics 206; Margalits Bolt) is annotated by Dugonics as deriving from a story about some thieves robbing a Jew who was riding a horse. Wishing to avoid any recognition of the stolen horse by passers-by, they cut the horse's belly, sew the Jew into it with his hair and beard protruding from underneath the horse's tail, thus making passers-by wonder what kind of creature this is. ${ }^{1}$ Other variants of this story-related saying are, as said: Se kin se ben mint a Zsidó

\footnotetext{
1 The Hungarian rendering of this story, including sexual innuendos about the hairy oversize organs of horse and Jew alike, is: "Egy lóháton menö Zsidót, úton értek a tolvajok. Mindenétül meg fosztották, de lovát el vinni nem merték : mert (különössége miat) reá ösmertek volna. Azt tehát ki hasitották, és úgy varták bele a Zsidót: hogy farka
} 
Rosen, Ilana. "The Representation of Jews in Nineteenth- and Twentieth-Century Hungarian Proverb Collections." Hungarian Cultural Studies. e-Journal of the American Hungarian Educators Association, Volume 10 (2017) DOI: 10.5195/ahea.2017.280

a lóban ['Neither outside nor in like the Jew in the horse'] (Erdély 8548); and Benne van, mint a zsidó a lóban ['He is inside, like the Jew in the horse'] (Margalits Benn).

If likening a thing to another through similes, using the preposition "like," constitutes a loose connection, because similitude allows the likened things to be also like many other things, then connecting two things by copulative verbs, meaning by metaphors denoting identification or characterization, creates a much stronger, committing connection. As literary historian and critic Northrop Frye explains in his Anatomy of Criticism, "In the metaphor two things are identified while each retains its own form. Thus if we say 'the hero was a lion' we identify the hero with the lion, while at the same time both the hero and the lion are identified as themselves" (Frye 1957: 123). This identification mechanism exists in the simple and direct metaphoric saying: Zsidó az ördög fúrója ['Satan's drill is Jewish'] (Sirisaka Zsidó; Margalits Fúró), which reverberates Medieval folk-religious beliefs about the Satanic traits of Jews (on which see: Trachtenberg 1943, Matteoni 2008, Resnick 2008); as well as in the shorter yet more elaborate and imaginative saying: Zsidó kézre került ['It got into Jewish hands'] (Erdély 8545). Related to their view as demonic in an everyday-life sense rather than in that of theological Heaven and Hell combats, Jews stand at the center of proverbs and saying reflecting their surrounding society's belief in, or fear of, their so-called magical power. These folk-beliefs are expressed in proverbs such as: Zsidóval találkozni szerencsét jelent ['Meeting a Jew means luck'] (Sirisaka Zsidó); and Aki a zsidónak nem köszön, átesik a küszöbön ['Whoever does not greet a (passing) Jew shall (have bad luck and) stumble on the threshold'] (Margalits Átesik, Köszön).

Metaphoric sayings starting with the phrase Zsidó van ['There's a Jew'] often portray the Jew as the ultimate Other, the one who stands out as not belonging. Examples of these are: Zsidó van a házban ['There is a Jew (meaning someone remaining with his hat on) in the house'] (Erdély 8539, Sirisaka Zsidó); or Zsidó van a kártyában ['There is a Jew (meaning one card not turned up-side-down as all the others) among the shuffled cards'] (Sirisaka Zsidó). Speaking of otherness, oftentimes Jews are listed among other Others, as in: Három Görög , három Török, három Zsidó: kilenc Pogány ['Three Greeks, three Turks, three Jews: nine pagans'] (Dugonics 69; Erdély 3513); Cigánykéz, zsidókéz, utolsó kéz ['Gypsy hand, Jewish hand, last hand (to count on for work)'] (Margalits Cigánykéz); and A bor legyen római katolikus hitében (erös), legyen református (tiszta), legyen zsidó (kereszteletlen) és legyen luteránus (se hideg, se meleg) ['Wine should be Roman-Catholic (strong), Reform (limpid), Jewish (un-baptized), and Lutheran (luke/tepid)'] (Margalits Katolikus). To these we can add the previously mentioned cunning Greek-Jew as a doubly foreign and menacing cheater, and the reference in Gabriella Vöö's twentieth-century collection to Jews and Gypsies being chased away from markets and fairs.

Considering the representation of different age groups in the studied corpus, except in the indirect allusion to a non-Jewish child forgetting to take off his hat when entering a house as a "Jew in the house," or to many a Jewish child supported by people indebted to their parents, children or youngsters do not figure much in this corpus. As for the representation of women, they are referred to in the curious adjectival idiom Aszonyok zsidoja ['A women's Jew'] (Sirikasa Zsidó), which could refer to a physically weak or unmanly man, Jewish or any, or implicitly

alatt szakállas és borzas feje jól ki teccenék. Ötet az arra menö emberek csudállották: hogy valamint lova, úgy bóttya is különös" (Dugonics 206). 
Rosen, Ilana. "The Representation of Jews in Nineteenth- and Twentieth-Century Hungarian Proverb Collections." Hungarian Cultural Studies. e-Journal of the American Hungarian Educators Association, Volume 10 (2017) DOI: 10.5195/ahea.2017.280

recall the Jewish religious matrimonial laws, by which couples are allowed to mate only on certain days of the woman's monthly fertility-cycle, which gives the wife control over the couple's sex life. (Jewish and cultural studies of national-revival processes among nineteenthcentury European societies deal much with the non-masculine, feminine image of Jewish men in these societies, including both religious learners and secular intellectuals, who during centuries of Diaspora life have allegedly grown estranged to nature with its seasonal cycles and strengthening, redeeming forces. The critique of the weakened or deformed Jewish masculinity received more expression in educated, higher-class discourse arenas than in those of lower-class folk yet it could not but sip through into these stages, too, as comes through in some of their proverbs and sayings; on which see: Gilman 1991, 2003, Gillerman 2003, Peleg 2006). We also find a saying by which Zsidó asszonyon mindig/mindenkor fityeg valami ['Something is always dangling on a Jewish woman'] (Dugonics 222; Erdély 8543; Sirisaka Zsidó), which portrays the Jewish woman as inelegant, lacking of good taste, or sexual in a cheap manner. The aforementioned metaphoric saying, "Sister, your shawl smells Jewish" refers to a non-Jewish woman who, unable to afford the shawl or whichever luxury she craves, becomes indebted to a sly Jewish vendor. In this saying the Jew's so-called seduction trick and the allusion to smell both work to evoke unpleasant, bothering sensual and sexual connotations, as happens otherwise in the other two sayings about or with women.

Curiously, none of the seventy to eighty proverbs about or with Jews in the four nineteenth-century collections refer to the ethos of the Jews they feature, e.g. their life-cycle and year-cycle customs or dietary laws, which are all highly visible, except the side-reference to Jews having pork as rare or inexistent. Nor are there any mentions in this corpus of higher or lowerrank Jewish sacra such as rabbi, teacher, learner, judge, ritual slaughterer, righteous persons, or of normative everyday Jews, the likes of whom house several works by a number of renowned nineteenth- and early-to-mid twentieth-century Hungarian writers such as József Eötvös, Mór Jókai, Kálmán Mikszáth, Zoltán Ambrus, Mihály Babits, and Zsigmond Móricz (Patai 1996, 665-666); not to mention Eastern-European Jewish-wit collections and studies like Dan BenAmos's voluminous collection referred to before regarding the Jew of Mád (Ben-Amos with Dov Noy 2007), and Yosef Guri's many Yiddish-Russian-English-Hebrew folk-wisdom collections (e.g., Guri 1993, 2000). These absences or gaps show that as far as these four proverb collections reflect, the gentile Hungarians living aside their village or small town or downtown Budapest Jews hardly noticed or cared about these Jews as a denomination with its traditions, or-more simply — as their everyday neighbors, friends, schoolmates, shoemakers, tailors, etc., with greedy Jewish shopkeepers and vendors constituting an unfavorable exception to this rule (although some of the narratives in Éva Huseby-Darvas's "Remembering Our Jews" article discussed later partly attenuate this grim depiction of the gaze of nineteenth-century Hungarians on "their" Jews).

The four nineteenth-century collections also never even mention the possibility of Jewish-gentile long-standing relations of any kind, like business, neighborly, friendly or romantic, much unlike in this period's literary works. By contrast, among the over three-hundred proverbs and sayings in three languages (Hungarian, Yiddish, and Romanian) that I recorded from my Erdély or Transylvanian father-in-law Saul Rosenzweig (1917-2004), there was one Yiddish proverb hinting at such attraction: Nito keyn meydlekh, tantst men mit shikses ['(If) there are no (Jewish) girls, one dances with gentile ones'] (Rosen 2011: 44, 46). All this means that the proverbs and sayings in these four collections are a very partial reflection of the presumed real- 
Rosen, Ilana. "The Representation of Jews in Nineteenth- and Twentieth-Century Hungarian Proverb Collections." Hungarian Cultural Studies. e-Journal of the American Hungarian Educators Association, Volume 10 (2017) DOI: 10.5195/ahea.2017.280

life relationship of Hungarians and Hungarian-Jews of the time, perhaps, as already suggested, because these collections were created with the motivation of presenting the spirit and sentiments of the Hungarian people, a project that left little room for respectful, amicable inclusion of groups such as Jews, Gypsies and other minorities.

Presenting a fuller picture than that afforded to us in nineteenth-century and probably early-to-mid twentieth-century proverbs, sayings, and stories, Éva Huseby-Darvas shows in her 1991 article that although the north-Hungarian elderly villagers in her study referred in their personal narratives to Jews in general through the lens of their own anti-Jewish church sermons and teachings, when it came to specific Jewish persons and families they had known in the interwar period, who "never returned" after World War II, they had only positive things to say about them (Huseby-Darvas 1991). Similarly, Veronika Görög-Karady traces in her 1992 article some of the Christian folk-religious origin legends and proverbial texts that instilled traditional Jew-hatred in their audiences irrespective of any flesh-and-blood Jews they may or may not have known (Görög-Karady 1992). Tamás Forgács (Forgács 1998), who wrote the Preface to the inclusive on-line volume with all four nineteenth-century proverb collections, and Wolfgang Mieder with regard to Nazi-German folkloristics (Mieder 1982, 1997), both explore the stereotypes and stereotypification procedures employed in anti-Semitic folk-religion, folklore per se, and political propaganda of the long twentieth-century (1789-1914). The studies of HusebyDarvas, Görög-Karady, Forgács and Mieder, including the rich source materials they rely on, invariably show how there is always a basis or grain of truth about the Jewish Other that is then swerved - often using powerful, persuasive, emotionally emphatic language - to portray this Other as utterly negative, harmful and menacing. This mechanism is so forceful that individuals and groups might find themselves using, reverberating, passing and eventually actually believing and living by such collective stereotypes, because they gradually come to perceive them as axiomatic truths.

In conclusion, in this article I explored the inventory of Hungarian proverbs and sayings about Jews from the last two centuries, which includes four nineteenth-century proverb collections presently easily accessible on the Internet and three twentieth-century collections, of which only one is available online and the other two exist only in print. The nineteenth-century collections proved to be relatively abundant with proverbs and sayings about Jews, featuring seventy to eighty such exemplars, whereas the twentieth-century collections are largely devoid of references to Jews. This difference can be explained by the norms of communism and especially its objection to surfacing inter-ethnic or religious cultural differences and conflicts. The nineteenth-century proverbs and sayings about Jews turned out to be rather unified in their common authoritative tone and in their recurring linguistic-syntactic features, such as giving Jews the role of grammatical-semantic object rather than subject, their wide use the disclaimer conditional-conjunction "even" before introducing Jews, and their even more widespread likening of negative entities and traits to Jews or Jewish. In their content, as shown, these seventy-to-eighty proverbs and sayings - of which some fifty are cited verbatim in this articlepresent Jews as faithless, dishonest and weak, and as Others ranging from powerful to pitiful. I then addressed conspicuous absences in this corpus, such as any respectful or at least neutral reference to Jewish ethos, customs, as to outstanding figures or ordinary yet positive ones, as well as to the possibility of benevolent relations of any kind between Hungarians and Jews.

Since proverbs are the parlance of the people, although their presentation in collections is the work of enthusiast folklore-collectors, I connected my linguistic and content analysis to the 
Rosen, Ilana. "The Representation of Jews in Nineteenth- and Twentieth-Century Hungarian Proverb Collections." Hungarian Cultural Studies. e-Journal of the American Hungarian Educators Association, Volume 10 (2017) DOI: 10.5195/ahea.2017.280

history of Hungary and its Jews in the last two centuries, showing that the indicting content and messages of these proverbs and saying, and later their tabooing out of the Hungarian culture, match the real history of Hungary and its Jews in the studied period. If Mary Gluck's conclusion in her study of the Fin de Siècle assimilated Budapest Jews and their contribution to the time's Metropolitan popular culture is that those Jews were both "invisible" and influential, then the conclusion of my exploration of the folk culture of more traditional Jews, seen through the eyes of avid collectors, is that far from invisible, these more ordinary Jews were noticeable yet dismissible, derided, detested and ultimately rejected.

\section{Works Cited}

Ben-Amos, Dan, ed. (with Dov Noy as consulting editor). 2007. Folktales of the Jews, vol. 2: Tales from Eastern Europe. Philadelphia: the Jewish Publication Society.

Braham, Randolph.1994. The Politics of Genocide: The Holocaust in HungaryRevised and Enlarged Edition, 2 vols. New York: Columbia UP.

Diabah, Grace and Nana Aba Apiah Amfo. 2015. "Caring Supporters or Daring Usurpers? Representation of Women in Akan Peoverbs." Discourse and Society 26.1: 3-28.

Dugonics, András. 1820. Magyar példa beszédek és jeles mondások ['Hungarian Exemplary Speech and Outstanding Sayings']. Szeged: Grünn Orbán. http://mek.oszk.hu/09100/09112/html/0001/27.html

Ember, Mária.1988. Jár-kel, mint zsidóban a fájdalom ['Comes and Goes, Like Pain in a Jew']. Budapest: Origo-Press.

Erdèly, János. 1851. Magyar közmondások könyve ['Book of Hungarian Proverbs'] http://mek.oszk.hu/09100/09112/html/0002/0.html

Flesch, Ármin. 1908. "A zsidó a Magyar közmondásban" ['The Jew in Hungarian Proverbs']. Izraelita Magyar Irodlami Társulat IMIT Évkönyv ['Israelite Hungarian Literary Company IMIT Yearbook']: 176-194.

Forgács, Tamás. 1998. "Cigány, zsidó meg a pap, hogy megcsalyon azon kap... avagy: hogyan születik és müködik a nyelvi sztereotípia," ['The Gypsy, Jew and Priest Hasten to Cheat You... - Or Do They: How Language Stereotypes Are Created and Work']. Néprajz és nyelvtudomány ['Ethnography and Language Studies'] 39: 87-105.

Frye, Northrop. 1957. Anatomy of Criticism - Four Essays. New Jersey: Princeton UP.

Gillerman, Sharon. 2003. "Samson in Vienna - the Theatrics of Jewish Masculinity." Jewish Social Studies, New Series 9.2: 65-98.

Gilman, Sander. 1991. The Jew's Body. New York: Routeldge.

-2003. Jewish Frontiers - Essays on Bodies, Histories, and Identities. New York: Palgrave Macmillan.

Gluck, Mary. 2016. The Invisible Jewish Budapest-Metropolitan Culture at the Fin de Siècle. Madison: U of Wisconsin P. 
Rosen, Ilana. "The Representation of Jews in Nineteenth- and Twentieth-Century Hungarian Proverb Collections." Hungarian Cultural Studies. e-Journal of the American Hungarian Educators Association, Volume 10 (2017) DOI: 10.5195/ahea.2017.280

Görög-Karady, Veronika. 1992. "Ethnic Stereotypes and Folklore - the Jew in Hungarian Oral Literature." Folklore Processed - in Honor of Lauri Honko on his 6-th Birthday, $6^{\text {th }}$ March 1992. Ed. Reimund Kvideland. Helsinki: Suomalaisen Kirjallisuuden Seura: 114-126.

Guri, Yosef. 1993. All's Well That Ends Well - a Dictionary of Proverbs: English, Russian, Yiddish, Hebrew. Jerusalem: Tarbut. .2000. Idiomatic Expressions in Yiddish and their Equivalents in English, Hebrew and Russian. Jerusalem: Hebrew University, Department of Russian and Slavic Languages.

Huseby-Darvas, Éva. 1991. "Remembering our Jews - the Complexity of Village Relations in North-Hungary." Jewish Folklore and Ethnology Review 13.1: 5-7.

Hussein, Jeylan Wolyie. 2009. "A Discursive Representation of Women in Sample Proverbs from Ethiopia, Sudan, and Kenya." Research in African Literatures 40.3: 96-108.

Kerschen, Lois. 2000. "Proverbs about Women from the Pacific Northwest and California." California History 79.1: 62-69.

Kovács, Mária M. 2012. Törvénytöl sújtva - a numerus clausus Magyarországon, 1920-1945 ['Down by the Law - the Numerus Clausus in Hungary, 19201945']. Budapest, Napvilág Kiadó.

Kovács, Tamás. 2014. Review: "Kovács, Mária M. 2012. Törvénytôl sújtva-a Numerous clausus Magyarországon, 1920-1945 ['Down by the Law - the Numerus Clausus in Hungary, 1920-1945']. Budapest, Napvilág Kiadó." Hungarian Cultural Studies 7: 82-84. https://ahea.pitt.edu/ojs/index.php/ahea/article/viewFile/167/193

Margalits, Ede. 1896. Magyar közmondások és közmondásszerü szólások ['Hungarian Proverbs and Proverbial Sayings'] http://mek.oszk.hu/09100/09112/html/0003/0.html

Matteoni, Francesca. 2008. "The Jew, the Blood and the Body in Late Medieval and Early Modern Europe." Folklore 119.2: 182-200.

Mieder, Wolfgang. 1982. "Proverbs in Nazi Germany: the Promulgation of AntiSemitism and Stereotypes though Folklore." Journal of American Folklore 95.378: 435-464. 1997. The Politics of Proverbs: from Traditional Wisdom to Proverbial Stereotypes. Madison, WI: U of Wisconsin P.

- 2006. "'The Proof of the Proverb is in the Probing': Alan Dundes as Pioneering Paremiologist." Western Folklore 56.3: 217-262.

Oişteanu, Andrei. 2009. Inventing the Jew - Antisemitic Stereotypes in Romanian and Other Central-East European Cultures (trans. Mirela Adascalitei). Jerusalem, Lincoln and London: Hebrew $\mathrm{U}$ and $\mathrm{U}$ of Nebraska P.

Paczolay, Gyula. 1991. 750 Magyar közmondás ['750 Hungarian Proverbs'] http://mek.oszk.hu/00200/00242/00242.htm 1997. Európai közmondások 55 nyelven - arab, perzsa, szanszkrit, kínai és japán megfelelökkel ['European Proverbs in 55 Languages with Equivalents in Arabic, Persian, Sanskrit, Chinese and Japanese']. Veszprém: Veszprém Nyomda. 
Rosen, Ilana. "The Representation of Jews in Nineteenth- and Twentieth-Century Hungarian Proverb Collections." Hungarian Cultural Studies. e-Journal of the American Hungarian Educators Association, Volume 10 (2017) DOI: 10.5195/ahea.2017.280

Patai, Raphael. 1996. The Jews of Hungary - History, Culture, Psychology. Detroit, MI: Wayne State UP.

Peleg. Yaron. 2006. "Heroic Conduct - Homoeroticism and the Creation of Modern Jewish Masculinities." Jewish Social Studies, New Series 13.1:31-58.

Resnick, Irven M. 2008. "Odo of Tournai and the Dehumanization of Medieval Jews - a Reexamination." The Jewish Quarterly Review 98.4: 471-484.

Reznikov, Andrey. 2009. Old Wine in New Bottles - Modern Russian Anti-Proverbs, Proverbium Supplement Series vol. 27. Burlington, VT: Vermont U.

Rosen, Ilana. 2011. Soul of Saul - the Life, Narrative, and Proverbs of a HungarianIsraeli Grandfather, Proverbium Supplement Series vol. 31. Burlington, VT: Vermont U.

Sándor, Klára. 2016. "Review: Szöllősy's, Éva. 2015. A férfiak és a nök képe modern értelmezö szótárainkban ['The Image of Men and Women in Our Modern Hungarian Dictionaries']. Budapest: Eötvös Loránd Tudományegyetem Kiadó." Hungarian Cultural Studies 9: 308-311. https://ahea.pitt.edu/ojs/index.php/ahea/article/viewFile/258/483

Scheiber, Alexander. 1954. "The Legend of the Wandering Jew in Hungary." Midwest Folklore 4.4: 221-235.

Sirisaka, Andor. 1890. Magyar közmondások könyve ['Book of Hungarian Proverbs'] http://mek.oszk.hu/09100/09112/html/0004/15687.html

Szalai, Anna, ed. 2002. In the Land of Hagar - the Jews of Hungary, History, Society and Culture. Tel Aviv: Beth Hatefutsoth.

Szöllősy's, Éva. 2015. A férfiak és a nők képe modern értelmezö szótárainkban ['The Image of Men and Women in Our Modern Hungarian Dictionaries']. Budapest: Eötvös Loránd Tudományegyetem Kiadó.

Trachtenberg, Joshua. 1943. The Devil and the Jews - the Medieval Conception of the Jew and its Relation to Modern Antisemitism. New Haven: Yale UP.

Vöö, Gabriella. 1989. Igaz ember igazat szól - közmondások a romániai magyar folklórból ['A Truthful Man Speaks the Truth - Proverbs of the Romanian-Hungarian Folklore']. Bucureşti: Kriterion Könyvkiadó.

Zenner, Walter P. 1971. "Stereotypes in Arabic Proverbs." Journal of American Folklore 83.330: 417-429. 